\title{
In Search of an International Tax System in a Post-BEPS Tax Competition Setting
}

\section{INTRODUCTION}

The discussion of the future of the international tax system is focused on identifying the right nexus to legitimize taxation of business activities, and on the allocation of taxing rights. Some recent ad hoc digital taxes, as well as proposals to introduce such taxes, are not dissociated from populist movements that states around the world have to face, and the tension caused by the fact that the international tax system is about national taxes and national budgets, as well as about citizens who vote for national taxes - all this in a tax competition setting. ${ }^{1}$

It has been rightly stressed that recent ad hoc digital taxes are not principles-oriented, they duplicate corporate income taxes and they introduce distortions in the framework of the tax system. ${ }^{2}$ This is why, when approved (at a regional or national level), they would need to be temporary (introducing sunset clauses, for example).

The future of the international tax system will depend on how successful states ultimately are in structuring the principles of taxation. The focus of this editorial is on the legitimacy to tax profits; the meaning of the benefit principle in the framework of the increasingly digitalized economy; and whether it is still possible for a state to tax global income.

\section{SOURCE AND THE BENEFIT PRINCIPLE}

Over thirty years ago, Intertax published a landmark article by Klaus Vogel on a review and re-evaluation of worldwide versus source-based taxation of income. ${ }^{3}$ In 1988, worldwide taxation of income was (still) linked to a non-discriminatory concept of income (taxes should cover all types of income equally) to be applied by the residence country, ${ }^{4}$ and source taxation of income with non-discrimination between foreigners and nationals. ${ }^{5}$

Residence and source are indicative of different levels of economic allegiance to a jurisdiction, but both mean that in the presence of economic allegiance, taxation is legitimate. Economic allegiance to a state could be based on mere consumption, or on business activities and passive investment.

Furthermore, economic allegiance has been assimilated to the benefit principle. In modern theory, the benefit principle applied to direct investment justified 'taxes as a consideration paid for the totality of state services by all taxpayers taken together'. ${ }^{6}$ Today, the OECD refers to the nexus rule, as a proxy for economic allegiance. The nexus rule is a condition for profit allocation rules based on transfer pricing and related to physical presence (incomeproducing activity physically taking place and excluding exports):

Under most tax treaties, business profits derived by an enterprise are taxable exclusively by the state of residence unless the enterprise carries on business in the other state (i.e., the source state) through a permanent establishment (PE) situated therein. This is sometimes called the 'nexus' rule (e.g., Articles 7 of the OECD and United Nations (UN) Model Tax Conventions), as it identifies the profits that are taxable by a country by reference to their relationship to a PE. The latter is generally defined by reference to a threshold that determines the circumstances in which a foreign enterprise is considered to have a sufficient level of economic activity in a state to justify taxation in that state. This threshold generally requires a certain level of physical presence of the foreign enterprise in the taxing jurisdiction, either through a 'fixed place of business' or through the actions of a 'dependent agent' (Articles 5

\section{Notes}

Ana Paula Dourado, Is There a Light at the End of the Tunnel of the International Tax System?, 46(8/9) Intertax 607, 609(2018).

See e.g. M. Devereux \& J. Vella, Taxing the Digitalised Economy: Targeted or System-Wide Reform, 4 Brit. Tax Rev. 381 (2018).

K. Vogel, Worldwide vs. Source Taxation of Income: A Review and Re-Evaluation of Arguments, 16(8/9) Intertax 216 et seq.; 10, at 310 et seq.; 11 , at 393 et seq. (1998).

Ibid., at 219

Ibid., at 217

Ibid., at 395 
of the OECD and UN Model Tax Conventions). For example, material operations in a market involving activities such as distribution, inventory management and local marketing (i.e., bricks and mortar economy) would typically be covered by this definition and thus meet the PE threshold. In contrast, the mere export of goods by a foreign enterprise that are not produced or distributed through a local facility would not be covered by this definition. Consequently, except where separate distributive rules apply (e.g., Articles 6, 10, $11,12,13$, or 17 of the OECD and UN Model Tax Convention), the determination of the jurisdiction with taxing rights depends on a nexus rule that looks at the substance of a business activity and attributes the primary right to tax to the country in which this incomeproducing activity physically takes place. ${ }^{7}$

Economic allegiance and nexus, in se, are as vague as the current post-Base Erosion and Profit Splitting (BEPS) principle of value creation, ${ }^{8}$ all of which can be reformulated and applied at each state's convenience or consensus reached at the OECD. It is clear that value creation is related, in substance, to a source concept, even if it is vague. ${ }^{9}$ Source refers to a state where value is added, ${ }^{10}$ as the place of the income generating activity. ${ }^{11}$

In 1988, according to Vogel, source was unambiguous only in what it excluded, namely residence and citizenship, according to Vogel. ${ }^{12}$ Currently, source does not exclude residence, because attribution of income to the residence also depends on value creation and on Development Enhancement Maintenance Protection and Exploitation of Intangibles (DEMPE) in the case of intangibles. Residence is becoming less relevant, and the meaning of source has been reopened by the discussion on the future of the international tax system.

Source does not (necessarily) exclude market, either, and non-discrimination between foreigners and nationals may require that market be taken into account as a relevant element in identifying source. In the brick-and-mortar economy, the selection of the place of activity - the physical presence also gave relevance to the dimension of the market.

As has been explained before, where a foreign enterprise had an important economic presence in a market, it would also have physical presence - activity - in that market, and in the current scale without mass economy, many market states no longer coincide with the place of production. ${ }^{13}$ This has certainly been driven by profitoptimization in economies of scale and by the Internet, ${ }^{14}$ but is also a result of tax competition. This mismatch has been cited to justify the United Kingdom diverted profits tax, as well as other similar taxes. ${ }^{15}$

As the OECD acknowledges, the digital economy and the associated:

scale without mass has led to an increasing share of the profits from cross-border activities not being taxed in the market jurisdiction, including in situations where the foreign enterprise has an important economic presence in that market. These impacts may highlight issues inherent in existing tax rules, which rely predominantly on physical factors to determine a taxable presence and allocate profits, when applied in the digital age. ${ }^{16}$

In the current digital economy, the benefit principle may also justify taxes as a condition to access the market of a country (business or final consumers), as sales at a distance do not directly benefit from the services of the state of destination. One could further claim that sales at a distance benefit indirectly from those public goods or services, by accessing the market where local consumers are.

Among the more than 110 members of the Inclusive Framework, some countries agreed that highly digitalized business models should result in changes to the international tax rules. ${ }^{17}$ In the European Union, the inclusion of market (and added value) in the source concept of the Common Consolidated Corporate Tax Base (CCCTB) Proposal of Directive was justified by the Commission as necessary to curtail aggressive tax planning:

the CССТВ features as an effective tool for attributing income to where the value is created, through a formula based on three equally weighted factors (i.e. assets, labour, and sales). Since these factors are attached to where a company earns its profits, they are more resilient to aggressive tax planning practices than the

\section{Notes}

OECD, Tax Challenges Arising from Digitalisation: Interim Report 2018 - Inclusive Framework on BEPS, OECD/G20 BEPS Project, at 168, para. 378 (OECD Publishing 16 Mar. 2018).

J. Hey, 'Taxation Where Value is Created', and the OECD/G20 Base Erosion and Profit Shifting Initiative, 72(4/5) Bull. Int'l Tax'n $203-206$ (Apr./May 2018).

Ibid., at 204-205; A. Martín Jiménez, BEPS, the Digitalized Economy and the Taxation of Services and Royalties, 46(8/9) Intertax 621 (2018).

Vogel, supra n. 3, at 223.

P. Musgrave, The International Tax Base Division and the Multinational Corporation, 27(4) Public Finance/Finances Publiques 397 (1972).

Vogel, supra n. 3, at 223.

M. De Wilde, Comparing Tax Policy Responses for the Digitalizing Economy, 46(6/7) Intertax 468 (2018)

Ibid.

H. Self, The UK's New Diverted Profits Tax: Compliance with EU Law, 43(4) Intertax 333-336 (2015).

OECD, Tax Challenges Arising from Digitalisation: Interim Report 2018, supra n. 6, at 170, para. 384.

Ibid., at 171, para. 389 . 
widespread transfer pricing methods for allocating profit. $^{18}$

The question today concerning the relevant source nexus is similar to that raised thirty years ago, but in a different type of economy: 'Where exactly is value added and how much, when an enterprise in state $A$ sells goods manufactured in state $B$, stored in state $C$, to an enterprise in $D$ - and, maybe, through an agent in $E$ ?'. ${ }^{19}$

\section{THE ROLE OF REPRESENTATION AND NON-DISCRIMINATION}

An argument of justice can be added. Local immovable consumers, who have to pay taxes, react to the fact that income accrued from sales at a distance is stateless ${ }^{20}$ and therefore untaxable, provoking a reduction of national public services as well as an increase in national taxes on those who have less ability to pay.

Non-discrimination between the new and traditional sectors of the economy also justify taxation of income derived from sales at a distance. From an international perspective, a company is not discriminated against if its combined tax burden is the same as the tax burden of other companies in the same jurisdiction and on the same income. It is therefore not surprising that the current pressure on the international tax system and on corporate income taxes comes from market countries and from their constituent consumers. ${ }^{21}$

Non-discrimination between sales at a distance (including digital sales) and domestic sales was a major achievement in the United States in the South Dakota v. Wayfair case (a case concerning an indirect tax), ${ }^{22}$ the rationale of which should be transposed to income taxes in the digital economy, based on production and sales of goods and services on a global scale. In South Dakota v. Wayfair, the Supreme Court of South Dakota sustained the tax on the basis of the following grounds: (1) it applies to an activity with a substantial nexus with the taxing State, (2) it is fairly apportioned, (3) it does not discriminate against interstate commerce, and (4) is fairly related to the services the State provides. ${ }^{23}$

Although determining the nexus is a condition to tax on the basis of equality at the national level, non- discrimination between domestic activities generating local sales and multinational activities generating sales at a distance contributes to alter the concept of economic allegiance. In a globalized economy, what matters is definition of source and whether source should include sales (in addition to capital and labour (or robots)).

\section{Taxing global income in the context OF TAX COMPETITION}

The old discussion of worldwide versus source taxation is still valid, but in very different terms. The discussion now takes place in the framework of tax competition and the resulting state's inability to decide alone and enforce taxation.

Taxation of global income has been targeted by multilateral coordination, such as the OECD/G20 BEPS Project. It is, for the moment, more difficult for taxpayers to introduce breaches to global income, and thereby to reduce taxes by circumventing rules on the tax bases.

The combination of different interrelated instruments, all of which have coordination purposes, aims to rescue the taxation of global income: the multilateral instrument (MLI) concluded in $2017 ;^{24}$ the BEPS Actions not converted in the MLI; the Anti Tax Avoidance Directive (ATAD 1 and 2); and also the base erosion alternative minimum tax or (BEAT)and taxation of global intangible low-taxed income (GILTI) at an effective 10,5\% introduced in the US Tax Reform Act of 22 December $2018 .^{25}$

The CCCTB proposal, as well as the proposals and measures towards taxing the digital sector in the marketplace, indicate that some countries are inclined to move away from the current international tax system, based on location of functions, assets and risks, and to include sales.

Presumably, government expenses in different states benefit their constituent and non-constituent residents physically present in the territory. Such expenses have been funded by taxes, such as corporate income taxes on multinationals, that are not directly related to the public services and goods offered.

In terms of principles, worldwide taxation can still be linked to the concept of income tax, a tax on global income, and a breach in global taxation still means a

\section{Notes}

18 Proposal for a Council Directive on a Common Consolidated Corporate Tax Base (CCCTB) COM/2016/0683 final - $2016 / 0336$ (CNS), Explanatory Memorandum, at 2.

19 Vogel, supra n. 3, at 223.

20 See E.D. Kleinbard, Stateless Income, 11 Fla. Tax Rev. 699 (2011).

21 Y. Brauner, Taxing the Digital Economy Post-BEPS, Seriously, 46(6/7) Intertax 463-465 (2018).

22 South Dakota v. Wayfair, Inc., et al., Supreme Court of South Dakota, at 17-494 (21 June 2018); R. Mason, Implication of Wayfair, 46(10) Intertax 810-819 (2018).

23 Ibid., e.g. at $8,23$.

24 OECD, Multilateral Convention to Implement Tax Treaty Related Measures to Prevent Base Erosion and Profit Shifting (OECD Nov. 2016).

25 R. Avi-Yonah \& G. Mazzoni, BEPS, ATAP, and the New Tax Dialogue: A Transatlantic Competition?, 46(11) Intertax 885-904 (2018); S. Shay, The US International Tax Reforms: Competition and Convergence, Pay-Offs and Policy Failures, 46(11) Intertax 905-913 (2018). 
breach in equity. Justice among taxpayers also used to require taxation of universal income in the state of residence.

As mentioned, in respect of business activities, residence is no longer a relevant connecting element. In the context of the digital economy, ideally, global income should be determined in one jurisdiction (e.g. that of the parent company), and split among the relevant source states (where country-by-country reporting permits verification).

Redistributive justice is a policy still carried out at the state level, according to national constitutional standards, independently of this being realistically possible, taking into account the tax competition scenario (and that states can no longer exercise their coercive powers in an effective manner, in an open globalized economy). ${ }^{26}$ However, redistributive justice does not per se legitimize taxation in the market place; taxation first needs a relevant nexus, as discussed above.

\section{Tax competition and the Tiebout MODEL}

Tax competition has accelerated to unprecedented values, and has been the main feature of the international tax system, even if it has been swinging back and forth between unilateral measures (some of them constructive unilateral measures) ${ }^{27}$ and multilateral coordination.

As taxes are a visible cost for companies, and in the absence of coordination or a supranational authority, free movement of capital and persons has led to tax competition in the attraction of capital and investment, in order to avoid a decrease in the productivity of labour. ${ }^{28}$

In light of the brick-and-mortar economy, it used to be disputed whether tax competition had more advantages than disadvantages. Some of the advantages of tax competition were explained by the old Tiebout metaphor of voting with the feet. ${ }^{29}$ Efficiency and welfare gains would be possible if different levels of services and taxes were offered and taxpayers could select the community that would best satisfy their personal preferences.

The Tiebout thesis has been challenged because, for example, the ratio public-goods and services versus taxes is not the same in the different states. Unlike the Tiebout model, investment would tend to move to jurisdictions where goods and services are offered at a lower price, provoking a snowball effect. Moreover, it seems that if taxes were based on the ability-to-pay principle and not on the cost-benefit, taxpayers with lower ability to pay would pay higher taxes. ${ }^{30}$

In the digital economy, it is even more difficult to apply the Tiebout metaphor of voting with the feet. Corporate income taxes will favour companies operating at a distance, because, as mentioned, they can obtain profits without directly benefitting from public goods or services, up to date in most countries, and without paying the costs for participating in the economy of the market country they target.

Moreover, the digital and dematerialized economies have fostered harmful tax competition among states, and the latter has in turn incentivized aggressive tax planning. Harmful tax competition and aggressive tax planning further distort the determination of source, and the desire by a sovereign state not to tax income, interferes with the desire of others to tax, and therefore with the allocation of taxing rights. In other words, the object of taxation is no longer clearly linked to one or two specific jurisdictions, and it has become difficult and controversial to identify the jurisdictions that are entitled to tax.

Whereas international taxation used to apply to a portion of the relevant economy and ability-to-pay, currently, multiple jurisdictions are openly competing to attract the same investment, and some - but not all - of those jurisdictions are competing to tax the same object. Furthermore, the taxing object is not clearly linked to the jurisdiction, in terms of determining source and residence.

The only clear point is that the tax object has a legal or factual nexus in several countries, the pie that is to be shared among states. Some will subsidize the pie in order to attract a part of it, while others seek not only to attract it, but also to tax it. Now and in the future, in respect of income taxes, the digital economy implies coordination of the share of the pie. This is why principles of taxation must be implemented by the different countries involved.

\section{Conclusion}

There is increasing support to allocate taxing rights to the country with relatively immobile consumers and users. ${ }^{31}$ This is so either by a destination based tax, which would

\section{Notes}

26 T. Dagan, International Tax Policy: Between Competition and Cooperation, Ch. 6 (Cambridge University Press 2018).

27 Avi-Yonah \& Mazzoni, supra n. 25.

28 J. A. Papke \& L. E. Papke, Measuring Differential State-Local Tax Liabilities and Their Implications for Business Investment Location, 39(3) Nat'l Tax J. 357-366 (1986).

29 C. Tiebout, A Pure Theory of Local Expenditures, 5 J. Pol. Econ. 416-424 (Oct. 1956).

30 Jorgen Lotz, The Role of the Government Local Taxation: The Tiebout Effect and Equalization, Comparative Tax Studies, Essays in Honour of Richard Goode 282-283 (Cnossen ed., North-Holland 1983); on the benefit principle and fiscal decentralization: Junghun Kim, Introduction, Interaction between Local Expenditure Responsibilities and Local Tax Policy 15-40 (Junghun Kim, Jørgen Lotz \& Niels Jørgen Mau eds, The Korea Institute of Public Finance and the Danish Ministry for Economic Affairs and the Interior 2015).

31 Y. Brauner, supra n. 21 
reallocate revenue in favour of big and/or relevant consumer markets; ${ }^{32}$ or profit splitting, where market would be acknowledged as a relevant factor; ${ }^{33}$ or by a simple withholding tax on gross income that would reallocate taxing rights in favour of source states. ${ }^{34}$ Withholding taxes would have an international redistributive effect, and it would be more difficult to reach a consensus. Profit splitting, in turn, would introduce a proportional allocation of taxing rights, still leaving to each state the redistributive role.

The OECD and the Inclusive Framework have an urgent task to carry out. The longer it takes, the greater the risk for a failure of multilateralism and a principled international tax system.

Ana Paula Dourado General-Editor

\section{Notes}

32 M.P. Devereux \& J. Vella, Implications of Digitalization for International Corporate Tax Reform, 46(6/7) Intertax 550-559 (2018).

33 L. Spinosa \& V. Chand, A Long-Term Solution for Taxing Digitalized Business Models: Should the Permanent Establishment Definition Be Modified to Resolve the Issue or Should the Focus Be on a Shared Taxing Rights Mechanism?, 46(6/7) Intertax 476-494 (2018).

34 E.g. A. Báez Moreno, A Note on Some Radical Alternatives to the Existing International Corporate Tax and Their Implications for the Digital(ized) Economy, 46(6/7) Intertax 560-564 (2018). 